\section{Kinga Frąckowska}

Uniwersytet Mikołaja Kopernika w Toruniu kinga.frackowska@op.pl

DOI: http://dx.doi.org/10.12775/BPTh.2016.011

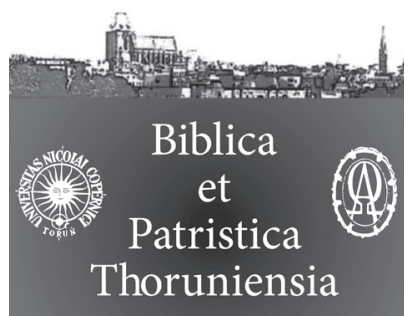

9 (2016) 2: 11-23

ISSN (print) 1689-5150

ISSN (online) 2450-7059

\title{
Gościć proroka to przyjąć słowo Boga. Eliasz u wdowy z Sarepty Sydońskiej (1 Krl 17,8-24)
}

\section{Hosting a prophet is like receiving God's Word. Elijah and the widow of Zarephath of Sidon \\ (1 Kings 17:8-24)}

Streszczenie. W czasie przedłużającej się suszy wdowa z Sarepty Sydońskiej przyjęła pod swój dach przybysza - Eliasza. Gościnność okazana prorokowi i przyniesionym przez niego słowom wniosły zmiany w życie kobiety. Dzięki zaufaniu okazanemu przez wdowę słowu obietnicy, Bóg rozwiązał kryzys żywnościowy w domu kobiety. Następnie dzięki pełnym zaangażowania reakcjom bohaterów na nagłą śmierć syna pani domu, Jahwe przywrócił chłopcu życie, wdowie status matki, a Eliaszowi pozycję wiarygodnego proroka. Prześledzenie opowiadania z 1 Krl 17,8-24 (przy wykorzystaniu narzędzi, którymi dysponuje analiza narracyjna) ma na celu ukazanie doniosłej, pierwszorzędnej roli słów Boga w tej historii, a także znaczenia komunikacji między pozostałymi bohaterami tej opowieści.

Abstract. During a prolonged drought the widow of Zarephath of Sidon takes home a newcomer - Elijah. The hospitality shown to the prophet and reliance on the words of promise result in changes in the woman's life. God solves the food crisis at the woman's home. Then by virtue of the full commitment of the characters in responding to the sudden death of the son of the mistress of the house, the boy's life is restored by the Lord, the widow recovers her status as a mother, Elijah gets into position of a reliable prophet. Analysis of the story of 1 Kings 17:8-24 (by means of tools proper to narrative inquiry) aims to show the prime role of the words of God in this story and the importance of communication between other characters.

Słowa kluczowe: Eliasz; 1 Księga Królewska; wdowa z Sarepty Sydońskiej; gościnność; Słowo Boga; prorok; analiza narracyjna.

Keywords: Elijah; 1 Kings; the widow of Zarephath of Sidon; the hospitality; the Word of God; the prophet; the narrative analysis. 
W a kartach Pisma Świętego można odnaleźć różnorodne opowiadania z zewnątrz, obcych. W kontekście aktualnej sytuacji geopolitycznej szczególnie często podnoszonym problemem w Europie jest zagadnienie gościnności i otwartości dla przybyszów, osób obcych kulturowo czy religijnie.

W 1 Księdze Królewskiej w rozdziale 17 spotykamy się z opowiadaniem mówiącym o Eliaszu, którego przyjęła pod swój dach wdowa z Sarepty Sydońskiej. Sarepta, miasto fenickie, pozostawało wówczas pod władzą króla Sydonu. Na tamtych terenach czczono inne bóstwa niż Bóg Jahwe, któremu służył Eliasz i o przywrócenie kultu którego się starał. Mimo że przybysz reprezentował inny lud i odmienne wierzenia, kobieta przyjęła proroka pod swój dach w czasie trwającej suszy.

Cykl opowiadań o Eliaszu nosi znamiona gatunku literackiego określanego mianem „legendy prorockiej”'. Niezależnie od trudności, jakie sprawiają teksty $1 \mathrm{Krl}$ 17,1-19.21 w jednoznacznym ustaleniu ich wartości historycznej, charakter tych opowiadań pozwala na prześledzenie treści rozdziału 17 przy wykorzystaniu narzędzi jakimi dysponuje analiza narracyjna ${ }^{2}$. W trakcie lektury tego opowiadania palącym staje się pytanie, kto właściwie jest głównym bohaterem tekstu. Wdowa, Eliasz czy może jeszcze ktoś inny? Kto pojawia się w roli gospodarza? Spróbujmy, odnosząc się do przebiegu narracji, kompozycji przestrzennej opowiadania i interakcji między bohaterami z 1 Krl 17,8-24 odpowiedzieć na te pytania i sformułować wnioski dotyczące nas samych. Kto i w jaki sposób chce być goszczony przez nas dzisiaj?

1 Por. J.St. Synowiec, Gatunki literackie w Starym Testamencie, s. 264-267; T. Tułodziecki, Eliasz. Słowo Boże lekarstwem na kryzys wiary proroka (1 Krl 17,1-19,21), s. 60.

2 Por. R. Rubinkiewicz, Nowe aspekty egzegezy biblijnej w świetle dokumentu Papieskiej Komisji Biblijnej „O interpretacji Biblii w Kościele”, s. 107. Papieska Komisja Biblijna przybliża analizę narracyjną jako jedną z metod odkrywania orędzia biblijnego. Por. Papieska Komisja Biblijna, Interpretacja Biblii w Kościele. Dokument Papieskiej Komisji Biblijnej $z$ komentarzem biblistów polskich, s. 35-37. O podstawowych elementach analizy narracyjnej (badanie fabuły i zwrotów akcji w opowiadaniu, charakterystyka bohaterów i zmian w nich zachodzących, czas opowiadania, perspektywa ukazywana przez narratora), choć przy stosowaniu odmiennej terminologii piszą m.in.: Z. Pawłowski, Hermeneutyczna metoda opowiadania we wspótczesnej egzegezie, s. 5-17; M. Gołębiewski, Struktura opowiadania jako podstawowa kategoria egzegezy i teologii narracyjnej, s. 58-66; W. Rakocy, Metoda narracyjna $w$ interpretacji tekstu biblijnego, s. 161-168; W. Rakocy, Nowe metody analizy literackiej w egzegezie Nowego Testamentu, s. 539-557; S. Szymik, Metoda narracyjna jako propozycja dialogu człowieka z tekstem, s. 11-20; S. Szymik, Współczesne modele egzegezy biblijnej, s. 59-79. 


\section{Treść opowiadania z 1 Krl 17}

Z perspektywy konstrukcji literackiej na kompozycję rozdziału 17 składają się trzy epizody ${ }^{3}$, w których łącznikiem jest postać Eliasza. Po wyschnięciu potoku, nad którym kruki karmiły proroka, Bóg kieruje słowo do Eliasza i poleca mu powędrować do Sarepty Sydońskiej (1 Krl 17,8). Zmienia się zatem miejsce akcji i pojawiają się nowi bohaterowie. W najbliższych sekcjach "nie występuje” Achab (jak w $1 \mathrm{Krl}$ 17,1) ani kruki, spotykamy natomiast Eliasza, wdowę i jej syna. Interakcje pomiędzy Eliaszem i wdową ściśle łączą dwie sekcje w. 8-16 i w. 17-24 w spójną historię.

Zwróćmy uwagę na przebieg akcji ww. 8-24. Eliasz posłuszny Bogu pragnie zrealizować Jego plan. Udaje się do wskazanej miejscowości, a czytelnik spodziewa się, że napotkana wdowa rzeczywiście udzieli prorokowi pożywienia. Kobieta posłuszna pierwszej prośbie Eliasza udaje się po kubek (naczynie) wody. Jednak druga prośba proroka odsłania problem, jakim jest skrajnie trudna sytuacja żywnościowa w domu wdowy spowodowana przedłużającą się suszą. Ujawnienie biedy i oczekiwania na śmierć głodową sprawia, że Eliasz podejmuje przyjętą wcześniej Bożą obietnicę o zapewnieniu pokarmu. W sposób poszerzony przedstawia kobiecie Boże słowa, co ją uspokaja i otwiera na gościnę wobec proroka. Dzięki jej ufności i przyjęciu Eliasza, mąka i oliwa rzeczywiście się mnożą. Jednak spokój bohaterów zostaje nagle zburzony nieoczekiwaną komplikacją: niespodziewanie umiera syn wdowy. Jej oburzenie i zarzuty postawione prorokowi popychają Eliasza do działania. Punktem zwrotnym staje się zaniesienie chłopca do izby na piętrze, błaganie Boga o interwencję, wskutek czego dziecko zostaje przywrócone do życia. Działania bohaterów i zaangażowanie się Boga przyczyniły się po pierwsze do zmiany sytuacji kobiety (od początku jest określana przez terminy związane ze śmiercią: wdowa, skutki trwającej suszy, posiadanie zaledwie resztek jedzenia, obawy przed nadchodzącą śmiercią, ujawnienie wyrzutów sumienia, śmierć jej jedynego syna) - od skupienia na śmierci i lęku do dostrzeżenia życia i bycia matką, a po drugie do poznania i określenia misji Eliasza - męża Bożego przynoszącego prawdziwe słowo Boga.

Eliasz przybywa do Sarepty, nawiązuje relację z wdową. Przez kolejne dni suszy to dzięki niemu zostaje zapewnione wyżywienie dla rodziny. Przyczynia się do wskrzeszenia chłopca. Czy jednak głównym bohaterem 1 Krl 17 jest

3 Por. M. Cogan., I Kings. A new Translation with Introduction and Commentary, s. 431-433; J.T. Walsh, 1 Kings, s. 227-233; N. Glover, Elijah versus the Narrative of Elijah. The Contest between the Prophet and Word, s. 453. 
Eliasz? Należy pamiętać, że przybywa do Sarepty na polecenie Boga. Przenosi się tam, dokąd posyła go Bóg przez swoje słowo ${ }^{4}$. To nakazy Boga są przyczyną zmiany miejsca pobytu proroka. Eliasz natychmiast reaguje na Boże polecenia. Staje się pośrednikiem Bożej obecności tam, dokąd przybywa. Całkowite oddanie proroka Bogu i przekazywaniu Jego słowa można również wywnioskować z faktu, że Bóg posługuje się ciałem Eliasza dla przekazywania swoich słów. W ww. 16 i 24 pojawiają się kolejno wyrażenia świadczące o tym, że Bóg wypowiada się za pośrednictwem ręki (b $\left.{ }^{\mathrm{e}} \mathrm{yā}\right)$ i ust ( $\mathrm{b}^{\mathrm{e}}$ pîkā) Eliasza ${ }^{5}$. Ponadto treść obietnicy o niewyczerpującym się dzbanie mąki i baryłce oliwy (w. 14), którą przynosi ze sobą prorok, staje się punktem odniesienia dla wdowy, która mimo początkowego oporu, decyduje się przyjąć Eliasza pod swój dach. To słowo przyjęte z zaufaniem, wiarą owocuje, rodzi konsekwencje w tej opowieści.

\section{Przestrzenne umiejscowienie akcji}

Pierwsza scena w historii dotyczącej proroka i kobiety rozgrywa się na otwartej przestrzeni (w. 10). Eliasz dopiero spotyka wdowę i rozmawia z nią niedaleko bramy u wejścia do Sarepty. Informacje o wnętrzu domu kobiety pojawiają się dopiero w w. 15, a szczegóły mówiące o jego wystroju w w. 19. Gdy prorok dowiaduje się o śmierci dziecka, zabiera je do górnej izby i kładzie na łóżku. Epizod z modlitwą Eliasza rozegra się na piętrze, a całość historii proroka i wdowy zakończy się zniesieniem jej syna do niższego pomieszczenia.

Warto zauważyć, że narrator relacjonuje historię i jej rozwój w ten sposób, że czytelnik przemieszcza się wraz z bohaterami z otwartej przestrzeni, z okolic

4 Por. N. Glover, Elijah versus the Narrative of Elijah, s. 453; Por. także: N.P. Lunn, Prophetic Representations of the Divine Presence: The Theological Interpretation of the ElijahElisha Cycle, s. 49-50. 63. W swoim artykule autor ukazuje Eliasza i Elizeusza jako posłańców przynoszących ze sobą obecność Boga, pozwalających innym doświadczyć teofanii. N. P. Lunn stara się wykazać związki pomiędzy terminologią stosowaną w cyklu opowiadań o Eliaszu i historiach dotyczących Elizeusza ze słownictwem opisującym realia świątyni Jerozolimskiej. Autor przedstawia interesującą interpretację działań proroków jako swoistą „rekompensatę” za brak dostępu do świątyni Salomona, którego doświadczała ludność Izraela po rozpadzie królestwa na część północną i południową w 931/930 r.

5 Por. N. Glover, Elijah versus the Narrative of Elijah, s. 452-453. W dalszej części wspomnianego artykułu autor zwraca uwagę, że w cyklu opowiadań o Eliaszu, to właśnie prorok jest postacią wypowiadającą się najczęściej - 30 razy. Dla porównania Jahwe przemawia ośmiokrotnie, wdowa trzy razy, a Baal ani razu. Słowa wyrażają czyjąś obecność i wpływają na wydarzenia. Istotne, że mowa Boga i Eliasza charakteryzują się tym samym autorytetem. To co obaj wypowiadają, dzieje się w rzeczywistości, kształtuje przyszłość. 
bramy wejściowej do Sarepty, do domu wdowy, a później z prorokiem i synem kobiety do górnej izby, aby ostatecznie zejść na dół do pozostającej tam kobiety i usłyszeć końcowe wypowiedzi głównych bohaterów. Rozwój fabuły stopniowo, w pewnej sekwencji przybliża bohaterów czytelnikowi, wraz z rozwojem wydarzeń można coraz bardziej wniknąć w sytuację i dramat sydońskiej wdowy. Początkowa prezentacja bohaterów przedstawia ich na otwartej przestrzeni, co zakłada istniejący dystans pomiędzy nimi, ale także pomiędzy bohaterami a czytelnikiem. Narrator prowadzi później czytelnika przez mieszkanie wdowy, informuje, że zmarły syn został zabrany z łona kobiety, ostatecznie zniesiony z górnego piętra i przywrócony matce. Czytelnik śledząc to opowiadanie, jest już blisko opisywanych postaci, w sercu dramatu, może wspiąć się razem z prorokiem na górne piętro i wrócić do wdowy uratowanej przed totalnym osieroceniem.

Konstrukcja przestrzenna opowiadania z 1 Krl 17,8-24 pozwala zobaczyć, że na tych wszystkich etapach rozwoju wątku dramatycznego bohaterom towarzyszy nie tylko narrator czy czytelnik, ale wypowiadane głośno słowo. Prorok i wdowa komunikują się zarówno na otwartej przestrzeni miejscowości, jak i w mieszkaniu kobiety. $\mathrm{Z}$ decydującą w tym opowiadaniu wypowiedzią Eliasza mamy do czynienia w górnej izbie, kiedy ten błaga Boga o interwencję i przywrócenie życia zmarłemu chłopcu ${ }^{6}$. Ostatnie słowa bohaterów spotykamy po zniesieniu ożywionego syna na niższe piętro. Przechodząc przestrzenną wędrówkę od Sarepty jako miejscowości do wnętrza mieszkania wdowy, czytelnik stopniowo wnika w świat bohaterów, przybliża się do ich dramatów, przeżyć, słów i działań. Tę samą drogę pokonuje słowo, które stało się obecne we wszystkich płaszczyznach życia wdowy. Towarzyszyło jej w pracy na wolnej przestrzeni, w obawach dotyczących nadchodzącej śmierci głodowej, w domowej codzienności wyrażanej przez obowiązki kuchenne, we frustracji spowodowanej śmiercią syna, w odzyskaniu żywego chłopca. Słowo i jego przyjęcie zaowocowały odczytaniem roli przybysza jako proroka przynoszącego słowo Boga, które odkryła jako prawdę. Ponadto, słowo wypowiedziane przez usta Eliasza przywróciło jej status matki, pozwoliło dostrzec życie i docenić Bożego wysłannika, który przyczynił się do zwrócenia jej żywego syna.

6 O kluczowej roli modlitwy wstawienniczej Eliasza piszą autorzy analizujący układ epizodu $1 \mathrm{Krl}$ 17,17-24, wskazując na jego chiastyczną strukturę. Por. R. Cohn, The literary logic of 1 Kings 17-19, s. 336; J.T. Walsh, 1 Kings, s. 230-231. 


\section{Rola słowa i komunikacji w 1 Krl 17,8-24}

Bóg przez swoje słowa kieruje Eliasza do Sarepty. Następnie prorok nawiązuje rozmowę z wdową. Pod wpływem pierwszej wymiany zdań z Eliaszem kobieta otwiera się na słowo proroka niosącego obietnicę Boga. Wdowa, po wyjawieniu swojej krytycznej sytuacji, okazuje zaufanie słowu „męża Bożego” i spełnia pierwotną prośbę Eliasza o wodę i jedzenie ${ }^{7}$. Skutkuje to wypełnieniem Bożej obietnicy o pomnażaniu żywności w ilościach niezbędnych do przeżycia. Bóg ukazuje się być obecny w tej historii poprzez swoje słowo i za jego pośrednictwem zaprasza bohaterów do współpracy $\mathrm{z}$ nim$^{8}$. Bóg zapewnia wyżywienie wdowie, jej synowi i prorokowi. Odpowiada też na modlitwę wstawienniczą, która prorok wygłasza nad zmarłym chłopcem i przywraca mu życie. Wdowa, po otrzymaniu syna żywego, potwierdza, że Eliasz niesie prawdziwie słowo Jahwe.

Prorok przedstawia się zatem jako narzędzie dla wypełniania planu Boga. Jest całkowicie oddany słowu Boga. Eliasz wysłuchuje bożych poleceń, przekazuje innym zapewnienia o jego obietnicach danych przez Boga. Czy to nie słowo Boga, przy współpracy z którym główne postacie uzyskują potwierdzenie bądź odnowienie swojej tożsamości, jest głównym bohaterem tej historii? Największym z owoców dialogu bohaterów, zaufania względem Bożego słowa i współpracy $\mathrm{z}$ nim $\mathrm{w}$ działaniu jest przywrócenie życia synowi wdowy.

W relacji z Bożą obietnicą i z jej wypełnieniem Eliasz i wdowa uzyskują określenie swojej tożsamości. Prorok zwraca wdowie utraconego syna, a ta na nowo staje się matką („zobacz, syn twój żyje” w. 23 - rề hay benêk). Przez słowo prorok przywraca jej tożsamość. Natomiast wdowa jako pierwsza werbalnie definiuje Eliasza jako proroka („męża Bożego” - 'îš hā'elōhîm). W 1 Krl 17,1 Eliasz nie jest określany mianem proroka (wiemy tylko, że był mieszkańcem Tiszbe w Gileadzie) $)^{9}$. Jest po prostu kimś mówiącym. Nie pojawiają się informacje o jego pochodzeniu, linii genealogicznej. Nie ma rodziców, przod-

7 Eliasz, kończąc rozmowę z wdową na temat posiłku, poleca jej, by uczyniła zgodnie ze swoim pierwotnym planem. Ostatecznie jednak kobieta nie realizuje własnego pomysłu, lecz wypełnia słowo Eliasza (1 Krl 17,13). Por. J. T. Walsh, 1 Kings, 230; Z. Pawłowski, Ożywienie zmartych $w$ cyklu opowiadań o Eliaszu i Elizeuszu, s. 21.

8 Por. M. Cogan, I Kings, s. 432.

9 Por. B.J. Łach, Księgi 1-2 Królów, 317-318. Znamienne, że w 1 Krl 17,1 w tekście TM Eliasz („Jahwe jest moim Bogiem”) nie jest określany mianem proroka, nazywa go tak dopiero LXX. W Księgach Królewskich Eliasz jest nazwany prorokiem tylko w 1 Krl 18,36, a w pozostałych przypadkach opisuje go sformułowanie „mąż Boży” - np. 1 Krl 17,18.24. 
ków, kogoś od kogo uzyskałby tożsamość jako spuściznę. Pierwszą osobą, która określa Eliasza jako „męża Bożego” jest właśnie wdowa, jako pierwsza głośno definiuje jego tożsamość ${ }^{10}$ i czyni to właśnie w odniesieniu do powierzonego mu zadania przekazywania słowa Boga (w. 24: debar Yahweh).

Eliasz jest przedstawiany jako narzędzie w przekazie Bożego słowa. Dzięki niemu słowo „wnika” w życie i obawy wdowy. Obecność Bożego słowa w dramacie kobiety jest uwydatniona przez pozycję Eliasza. Początkowo jest kimś obcym dla wdowy. Nawiązują jednak relację i zostaje przyjęty do jej domu. Jest karmiony tym, co rodzina posiada w mieszkaniu - w ten sposób stawia się w pozycji dziecka (jak syn wdowy - karmiony przez panią domu) ${ }^{11}$. Dzięki jego obecności to Bóg zaczyna żywić całą rodzinę. Zapewnienie gościom posiłków jest zazwyczaj obowiązkiem gospodarza. Dzięki obecności proroka Bóg spełnia obietnicę i przejmuje kontrolę nad życiem rodziny. Przez przywrócenie życia chłopcu Jahwe okazuje się być Panem rzeczywistości, w której są zanurzeni bohaterowie. Wdowa przyjęła przybysza, ale tak naprawdę przyjęła sługę Bożego słowa, a ono zaczęło mieć decydujący wpływ na kształtowanie jej świata.

Warto zauważyć, że słowo Eliasza ma niezwykłą moc. Skuteczność wypowiedzi proroka stawia jego słowa na równi $z$ autorytetem słów Boga ${ }^{12}$. Po jego zapowiedzi zapanowała susza $(1 \mathrm{Krl} 17,1)$. Po podjęciu i przekazaniu szerszego komunikatu o obietnicy pomnażania żywności rodzina przez dłuższy czas ma zapewniony pokarm. Po modlitwie błagalnej Eliasza ${ }^{13}$ Bóg przywraca dziecku życie, kobiecie status matki, a przybyszowi pozycję wiarygodnego proroka.

10 Por. N. Glover, Elijah versus the Narrative of Elijah, s. 452. Wdowa nazywa Eliasza „mężem Bożym” już w w. 18, jednak czyni to wówczas w ramach wyrzutu, rozgoryczenia spowodowanego śmiercią syna. W w. 24 kobieta potwierdza tożsamość Eliasza, jest już pewna, że on rzeczywiście przyszedł do niej jako prawdziwy sługa Boga. Por. S.J. DeVries, 1 Kings, s. 222.

11 Por. A. Kalmanofsky, Women of God, s. 62.

12 Por. D. Dziadosz, Eliasz - starotestamentalny typ obrońcy wiary w jedynego Boga Jahwe i Jego Prawa, s. 9.

13 Prorok w swojej prośbie zwraca się bezpośrednio do Boga, a jednocześnie pozostaje bliski ciału chłopca. Wołanie, w które zaangażowana jest cała osoba Eliasza, zostaje wysłuchane przez Boga. Życie wraca do chłopca, a postać proroka w tym zdarzeniu pośredniczy. O związku pomiędzy komunikacją, podtrzymywaniem relacji i wypowiadanym słowem zwłaszcza błagalnym zobacz więcej w: H. Witczyk, „Pokorny wołał i Pan go wystuchat” (Ps 34, 7 a). Model komunikacji diafanicznej w Psalmach. 


\section{1 Krl 17 a cykl opowiadań o Eliaszu}

Historia pobytu Eliasza u wdowy z Sarepty Sydońskiej nie jest jedynym tekstem opisującym działalność proroka. W dalszej lekturze Ksiąg Królewskich warto odczytać epizod sarepski jako fragment większej całości - najpierw w ramach cyklu o Eliaszu (1 Krl 17,1 - 2 Krl 2,13), a następnie w kontekście paralelnego opowiadania o wskrzeszeniu syna Szunemitki przez Elizeusza ( $2 \mathrm{Krl} 4,8-37)$. 1 Krl 17,8-24 może stanowić „furtkę” przez którą wnikniemy głębiej w świat biblijnych narracji ${ }^{14}$. Postaci występujące $\mathrm{w}$ epizodach dotyczących Eliasza i jego misji charakteryzuje pewne podobieństwo zachowań, ale pojawiają się także bohaterowie zestawieni na zasadzie ekspozycji antytetycznej. Bohaterem podobnym do Eliasza jest zdecydowanie Elizeusz (jego następca, spadkobierca posłannictwa prorockiego). Wdowa przyjmująca proroka w Sarepcie nosi znamiona upodabniające ją do Obodiasza, który ukrył proroków przed Izebel (1 Krl 18,3-4). Ta postać z kolei znana z imienia, pochodzenia, pozycji społecznej, działań na rzecz wsparcia proroków Baala - jest swego rodzaju antytypem wdowy, kobiety anonimowej, dającej schronienie prorokowi Boga Jahwe ${ }^{15}$.

Interesującą rolę w opowiadaniach o Eliaszu odgrywa wielokrotne stosowanie ironii przez jej autora (autorów). Cechy ironii można odczytać w opisach sytuacji czy tła przestrzennego. Eliasz reprezentujący Boga Jahwe ukrywa się w Sarepcie, mieście fenickim podlegającym pod władzę Sydonu. Królem Sydonu jest zaś ojciec Izebel. Zatem mąż Boży chroni się niemal w „obozie wroga”. Walka o ukazanie Jahwe jako jedynego Boga, w której uczestniczy Eliasz, angażuje całą przyrodę. Pora sucha nienaturalnie się przedłuża, wszystko zamiera, a przecież tamtejsi mieszkańcy czczą boga płodności, deszczu i wegetacji. Mimo, że wszędzie wokół panuje susza, Eliasz ma nieustannie zapewnione warunki niezbędne do przeżycia i to przebywając na wrogiej ziemi. Wyrazem silnej ironii jest też sarkazm słowny, jaki spotykamy w historii walki z pogańskimi prorokami na górze Horeb (1 Krl 18,27), kiedy Eliasz wzywa konkurentów do głośniejszego przyzywania Baala, gdyż ten może „jest zajęty albo śpi”. W opowiadaniu o pobycie proroka w Sarepcie także pojawia się element ironiczny. Wdowa, silnie poruszona śmiercią syna, podważa misję Eliasza, nazywając go

14 O podobieństwach i różnicach pomiędzy opowiadaniami o wskrzeszeniu zmarłych przez Eliasza (1 Krl 17,8-24) i Elizeusza (2 Krl 4,8-37) można przeczytać w: D.J. Zucker, Elijah and Elisha: part II similarities and differences, s. 19-23 oraz Z. Pawłowski, Ożywienie zmarlych w cyklu opowiadań o Eliaszu i Elizeuszu, s. 17-34.

15 Por. J.T. Walsh, 1 Kings, s. 262-263. 
złośliwie „mężem Bożym”. Dalsze wydarzenia powodują porzucenie ironicznego tonu i pozytywne potwierdzenie posłannictwa proroka przez wdowę.

Historia z Krl 17,1-24 odnajduje też swoje miejsce w szerszej konstrukcji cyklu historii o Eliaszu, gdy zwrócimy uwagę na główne przesłanie teologiczne dziejów proroka. Kluczowym wydarzeniem, w którym bierze udział Eliasz, jest pokonanie proroków Baala na górze Karmel (1 Krl 18,20-40). „Mąż Boży” ze swoim zaangażowaniem na rzecz walki o kult jedynego Boga Jahwe wchodzi na tereny, na których czczono Baala. W zmianach pór roku, porze deszczowej i suchej obserwowano walkę Baala (bóstwo deszczu, płodności) z Motem (władającym śmiercią) ${ }^{16}$. Eliasz ukazuje na górze Karmel Boga Jahwe jako jedynego władcę przyrody. Poza tym poprzez słowa kierowane kilkakrotnie do Achaba udowadnia, że sam jest prorokiem Boga odpowiedzialnego za nienaturalne przedłużanie się suszy, a potem przywrócenie deszczu. Zewnętrzna walka z bóstwami kananejskimi (w którą zaangażowani są bohaterowie pierwszoplanowi, statyści, ale też cała przyroda jako tło) nie jest jednak jedynym zmaganiem przedstawionym w ramach opowiadań o Eliaszu. Mimo zwycięstwa nad fałszywymi prorokami i Baalem, musi się jeszcze dokonać pokonanie śmierci, która wewnętrznie „dotyka” bohaterów. Najpierw wdowa z Sarepty przeżyje śmierć i wskrzeszenie syna, na powrót stanie się matką. Znamienne, że pewien kryzys i wewnętrzną walkę między życiem i śmiercią przeżyje także sam prorok. Przerażony zapowiedziami Izebel ucieknie samotnie na pustynię, pragnąc umrzeć $^{17}$. Bóg zatroszczy się o niego i to tak dobitnie, że Księgi Królewskie nie opiszą w ogóle jego śmierci. $2 \mathrm{Krl}$ 2,11 poinformuje czytelników o pojawieniu się wozu ognistego i tajemniczym wzięciu proroka do nieba. Walka z kultem bożków mających być odpowiedzialnymi za umieranie i życie musi dokonać się nie tylko na płaszczyźnie zewnętrznych czynów, przejawów czci.

Patrząc na dynamikę postaci wdowy i proroka, można dostrzec ich wewnętrzne, osobiste zmaganie $z$ doświadczeniem śmierci i życia. Świadome, ustawiczne przyjmowanie słowa Boga może mieć wpływ na identyfikowanie i uznawanie Boga Jahwe jako jedynego Pana życia i śmierci. Słowo Boga ma władzę nad życiem i umieraniem, nadaje i określa czyjąś funkcję i zadania (bycie matką czy prorokiem).

16 Por. R.M. Good, Baal, s. 74-75.

17 Istotne, że decydującą rolę w przejściu przez kryzys wiary proroka odegra także słowo Boga, jego przyjęcie i działanie zgodnie z nim. Por. T. Tułodziecki, Eliasz. Słowo Boże lekarstwem, s. 63-71. 


\section{Aktualne przesłanie opowiadania}

Analiza epizodów z 1 Krl 17,8-24 przy zwróceniu uwagi na miejsce akcji, tło przestrzenne opisanych zdarzeń oraz interakcje między występującymi postaciami pozwalają na stwierdzenie, że wyraźnie zarysowanymi bohaterami opowiadania są prorok Eliasz oraz wdowa z Sarepty Sydońskiej. Jednak to słowa, które słyszą, ale też wypowiadają, owocują zmianami zachodzącymi w nich samych lub w odczytaniu (potwierdzeniu) ich tożsamości przez innego bohatera. Wyraźnie zarysowane postaci mogą stanowić punkt odniesienia dla czytelnika, który ma możliwość zidentyfikowania się z którymś z bohaterów i jego historię uczynić kanwą dla odczytania własnego życia ${ }^{18}$. W ten sposób uważne śledzenie narracji z Pisma Świętego może stać się okazją dla lektury egzystencjalnej. Czytelnik, gdy odnajdzie w przeczytanej historii miejsce dla siebie, kiedy utożsami swoją historię ze zdarzeniami i uczuciami przypisywanymi którejś z postaci, będzie miał szansę zyskania umiejętności odczytania analogicznych zdarzeń ze swojego życia jako wpływających na jego aktualną sytuację i tożsamość ${ }^{19}$. Tekst biblijny jako podstawa takiej lektury będzie miał wówczas okazję stać się punktem odniesienia dla podejmowanych przez czytelnika decyzji, opowiadaniem mogącym nadać orientację wyborom i całemu $\dot{z ̇ y c i u}^{20}$. Ponadto podczas lektury słów Pisma Świętego czytelnik ma szansę sam podjąć dialog, nie tylko z bohaterami opowiadania, ale też z Bogiem, który przez $\mathrm{w}$ tej historii się objawia ${ }^{21}$. Warto na bazie przestudiowanego opowiadania zastanowić się, jakie pytania egzystencjalne może „zadać” czytelnikowi słowo Boże przez wykreowane przez narratora postaci Eliasza i wdowy obecne w $1 \mathrm{Krl} 17,8-24$.

Mieszkanka Sarepty sydońskiej weszła w dialog z prorokiem nieznanego jej bliżej Boga Jahwe. Na jego drugą prośbę dotyczącą przyniesienia czegoś do spożycia, odpowiedziała, odkrywając swoją dramatyczną sytuację. Otworzyła się jednak na Bożą obietnicę wyjawioną przez Eliasza. Okazane zaufanie przyniosło wszystkim wsparcie Boga wyrażone przez pomnażanie mąki i oliwy. Kiedy sytuacja rodziny nieoczekiwanie uległa zmianie, kobieta wyraziła swoje oburzenie i rozgoryczenie, kierując do proroka słowa pełne rozczarowania i wyrzutów. Po otrzymaniu z powrotem żywego syna, kobieta upewniła się co do prorockiej misji przybysza i niezachwianego autorytetu słowa, które ze sobą

\footnotetext{
18 Por. H. Witczyk, Czytelnik jako wspót-kreator postaci, s. 88.

19 Por. Z. Pawłowski, Opowiadanie Bóg i początek, s. 228-229.

20 Por. idem, Hermeneutyczna metoda opowiadania, s. 16-17.

21 Por. H. Witczyk, Dialog Boga z człowiekiem, s. 19.
} 
przyniósł. Postać wdowy, jej zachowanie i przytaczane słowa mogą być okazją dla czytelnika do przemyślenia osobistych postaw, do analizy własnych zachowań, ale też do kształtowania życia duchowego i motywacji wewnętrznych na podstawie słowa Bożego. Historia wdowy i jej postawa w stosunku do Eliasza, niosącego słowa Boga, może „pytać” czytelnika o jego postawę gościnności, nie tylko wobec ludzi, ale wobec Boga obecnego w tekście Pisma Świętego. Czy czytając Biblię, jesteśmy gotowi na zaufanie słowu, na poświęcaniu mu czasu, na stratę czegoś, co dotąd było obecne w naszym życiu czy porządku na dnia, na rzecz obcowania z Bożym słowem ${ }^{22}$ ? Czy do słowa Bożego powracamy w chwilach egzystencjalnie trudnych, czy potrafimy Pismo Święte traktować jako Słowo-Osobę, wcielone w osobie Chrystusa, czy potrafimy wypowiedzieć przed Nim dramaty i ból straty w wielorakich dziedzinach osobistego życia? Czy zapamiętujemy, co w naszej historii wyjaśniło się, rozwiązało pod wpływem Bożego Słowa? Czy kiedykolwiek uznaliśmy autorytet i moc Słowa działającego w człowieku? Czy Bóg wypowiadający Słowo jest kimś obcym dla mnie, czy miał okazję stać się moim Bogiem? Czy wracam do Słowa w celu jego interioryzacji, lektury całożyciowej i stałej? Czy buduje to moją wiarę, czy jest ona wciąż rzeczywistością, o której myślę okazjonalnie? Czy jestem otwarty na pogłębianie zaangażowania w lekturę Pisma Świętego w celu odkrywania osoby Boga w Słowie mogącym być obecnym we wciąż nowych okolicznościach życia?

Eliasz to postać, której tożsamość wyraża się już w nadanym jej imieniu. Prorok służy Bogu, a więc wydaje się Go znać i uznawać za osobisty punkt odniesienia i źródło posłannictwa. „Mąż Boży” może nas pytać o zaufanie Słowu Boga, o gotowość natychmiastowego działania według Bożych poleceń. Eliasz wypowiedział Bogu żal związany ze śmiercią syna wdowy. Czy próbujemy dialogować ze Słowem Bożym nawet w sytuacjach trudnych, frustrujących? Czy to Słowo jest bodźcem dla naszych działań? Czy odczytaliśmy w świetle Słowa swoją tożsamość i powołanie, a jeśli tak, czy wracamy do Pisma Świętego, aby się upewniać, co do swojej życiowej „misji”, podjętych działań i szukać dalszego kierunku? Czy w kryzysie wypowiadamy przed Bogiem swój aktualny dramat? Czy jesteśmy świadomi, że wiara w Boże Słowo może przynosić owoce nie tylko w nas, ale też w innych? Czy powracamy regularnie do Słowa, by miało szansę przenikać życie, kształtować myślenie i działanie? Czy na wzór Eliasza dostrzegamy w lekturze Pisma Świętego szansę dla modlitwy wstawienniczej, gdy nasza ufność i wyrażanie całych siebie w dialogu ze Słowem może

22 O potrzebie poświęcania czasu na osobistą, pogłębioną lekturę Pisma Świętego, pisze papież Franciszek, powołując się na nauczanie Jana Pawła II. Por. Adhortacja apostolska Evangelii Gaudium, Kraków 2013, s. 80-81. 
zaowocować dla dobra innych ${ }^{23}$ ? Czy Słowo Boga jest Panem i „Gospodarzem” mojego życia?

Wdowa z Sarepty Sydońskiej przyjęła przybysza, otwierając się na przekazane słowo obietnicy. Bóg Jahwe za pośrednictwem posłusznego mu wysłannika stał się obecnym w życiu kobiety. Dzięki współpracy bohaterów z otrzymanym słowem, Bóg zainterweniował rozwiązując kryzys żywnościowy spowodowany suszą, ale także przywrócił do życia syna sarepskiej wdowy. Słowo Boga przyjęte przez postaci opowiadania oraz ich reakcje na nie a także komunikacja między bohaterami nadają dynamizmu opowiadaniu z $1 \mathrm{Krl}$ 17,8-24. Słowo ma wpływ na rzeczywistość i definiowanie tożsamości Eliasza i kobiety. Ponadto Bóg Jahwe poprzez swojego proroka staje się głównym bohaterem i Panem tej historii, mającym władzę nad suszą, pokarmem, życiem i śmiercią.

\section{Bibliografia}

Benedykt XVI, Adhortacja apostolska Verbum Domini, Kraków 2010.

Franciszek, Adhortacja apostolska Evangelii Gaudium, Kraków 2013.

Papieska Komisja Biblijna, Interpretacja Biblii w Kościele. Dokument Papieskiej Komisji Biblijnej z komentarzem biblistów polskich, red. R. Rubinkiewicz, Warszawa 1999.

Cogan M., I Kings. A new Translation with Introduction and Commentary (The Anchor Bible), Doubleday 2001.

Cohn R., The literary logic of 1 Kings 17-19, Journal of Biblical Literature 101 (1982) nr 3, s. 333-350.

DeVries S.J., 1 Kings (Word Biblical Commentary), Waco 1985.

Dziadosz D., Eliasz - starotestamentalny typ obrońcy wiary w jedynego Boga Jahwe i Jego Prawa, Collectanea Theologica 74 (2004) nr 1, s. 5-20.

Glover N., Elijah versus the Narrative of Elijah. The Contest between the Prophet and Word, Journal for the Study of the Old Testament 30 (2006) nr 4, s. 449-462.

23 O wyjątkowej roli Pisma Świętego w kształtowaniu osobistej modlitwy pisał Benedykt XVI. Por. Benedykt XVI, Adhortacja apostolska Verbum Domini, s. 31. Papież zwraca uwagę na teksty biblijne stanowiące świadectwo słów spisanych mogących służyć jako pomoc w nauce modlitwy wyrażającej i rozwijającej relację z Bogiem. Takimi formami są m.in. znajdujące się w Piśmie Świętym przykłady modlitw wstawienniczych, Psalmy, słowa skargi. Ze szczegółową analizą treści Psalmów jako modelu komunikacji, w którym dwa podmioty w sposób werbalny wyrażają swoją sytuację i istotę, wzajemnie na siebie oddziałują i budują czy aktualizują istniejącą już relację, mamy do czynienia we wspomnianej już pozycji: H. Witczyk, „Pokorny wołał i Pan go wystuchat (Ps 34, a)”. 
Gołębiewski M., Struktura opowiadania jako podstawowa kategoria egzegezy i teologii narracyjnej, Ateneum Kapłańskie 123 (1994) z. 1, s. 58-66.

Good R.M., Baal, w: Encyklopedia biblijna, red. P. J. Achtemeier, Warszawa 1999, s. 74-75 .

Język Biblii. Od słuchania do rozumienia, red. W. Pikor, Kielce 2005.

Kalmanofsky A., Women of God: Maternal Grief and Religious Response in 1 Kings 17 and 2 Kings 4, Journal for the Study of the Old Testament 36 (2011) nr 1, s. 55-74.

Lunn N.P., Prophetic Representations of the Divine Presence: The Theological Interpretation of the Elijah-Elisha Cycle, Journal of Theological Interpretation 9 (2015) nr 1, s. 49-63.

Łach J.B., Księgi 1-2 Królów: wstęp, przekład z oryginału, komentarz, ekskursy, (Pismo Święte Starego Testamentu: Tom IV, część 2), Poznań 2007.

Pawłowski Z., Hermeneutyczna metoda opowiadania we współczesnej egzegezie, Collectanea Theologica 62 (1992) nr 1, s. 5-17.

Pawłowski Z., Opowiadanie, Bóg i początek: teologia narracyjna Rdz 1-3, (Rozprawy i Studia Biblijne 13), Warszawa 2003.

Pawłowski Z., Ożywienie zmarłych w cyklu opowiadań o Eliaszu i Elizeuszu, Verbum Vitae 15 (2009), 17-34.

Rakocy W., Metoda narracyjna w interpretacji tekstu biblijnego, Ruch Biblijny i Liturgiczny 48 (1995) nr 3, s. 161-168.

Rakocy W., Nowe metody analizy literackiej w egzegezie Nowego Testamentu, w: Wstęp do Nowego Testamentu, red. R. Rubinkiewicz, Poznań 1996, s. 539-557.

Rubinkiewicz R., Nowe aspekty egzegezy biblijnej w świetle dokumentu Papieskiej Komisji Biblijnej „O interpretacji Biblii w Kościele”, w: Interpretacja Biblii w Kościele. Dokument Papieskiej Komisji Biblijnej z komentarzem biblistów polskich, red. R. Rubinkiewicz, Warszawa 1999, s. 101-116.

Synowiec J.St., Gatunki literackie w Starym Testamencie, Kraków 2003.

Szymik S., Metoda narracyjna jako propozycja dialogu człowieka z tekstem, w: Język Biblii. Od stuchania do rozumienia (Studia Biblica 11), red. W. Pikor, Kielce 2005, s. $11-20$.

Szymik S., Współczesne modele egzegezy biblijnej, Lublin 2013.

Tułodziecki T., Eliasz. Słowo Boże lekarstwem na kryzys wiary proroka (1 Krl 17,1-19,21), w: Świadkowie wiary. Biblia o wierze, red. D. Dziadosz (Analecta Biblica Lublinensia 10), Lublin 2014, s. 58-73.

Walsh J.T., 1 Kings (Berit Olam), Collegeville 1996.

Witczyk H., Czytelnik jako wspót-kreator postaci, w: Język Biblii. Od słuchania do rozumienia (Studia Biblica 11), red. W. Pikor, Kielce 2005, s. 70-89.

Witczyk H, Dialog Boga z człowiekiem jako główny przedmiot egzegezy, w: Interpretacja (w) dialogu. Tożsamość egzegezy biblijnej, red. A. Kucz, A. Malina, (Studia Biblica 10), Kielce 2005, s. 11-27.

Witczyk H., „Pokorny wołat i Pan go wystuchał” (Ps 34, 7 a). Model komunikacji diafanicznej w Psalmach, Lublin 1997.

Zucker D. J., Elijah and Elisha: part II similarities and differences, Jewish Bible Quarterly 41 (2013) nr 1, s. 19-23. 